\title{
Uniwersały królewskie i ich rola w procesie przygotowania działań wojennych na szczeblu powiatu w XVII wieku
}

Zagadnienie dokumentu oraz innych produktów kancelarii monarszej okresu staropolskiego to temat słabo rozpoznany. W porównaniu z badaniami kancelarii królewskiej okresu średniowiecznego, które zapoczątkowano dawniej i kontynuowano aż do czasów współczesnych ${ }^{1}$, dla epoki nowożytnej, mimo istnienia kilku wartościowych prac dotyczących organizacji kancelarii królewskiej $^{2}$ i jej personelu ${ }^{3}$, brakuje podstawowych studiów nad jej produkcją aktową, ogarniających przynajmniej okres panowania jednego władcy.

Wartościowe charakterystyki zawartości głównych serii ksiąg ${ }^{4}$ nie rozwiązują problemu, bowiem kancelaria królewska oprócz nich sporządzała znaczne ilości przywilejów, mandatów, uniwersałów czy listów, których nie poddawano gruntowniejszym analizom. Pewną nadzieję na poprawę sytuacji można wiązać

${ }^{1}$ Ze starszych prac F. Nowicki, Studia nad kancelariq koronnq Kazimierza Jagiellończyka, Lwów 1912. Z nowszych przede wszystkim prace I. Sułkowskiej-Kurasiowej, Dokumenty królewskie $i$ ich funkcja $w$ państwie polskim za Andegawenów i pierwszych Jagiellonów 1370-1444, Warszawa 1977; ejusd., Polska kancelaria królewska w latach 1447-1506, Wrocław 1967, w których dalsza literatura.

A. Tomczak, Kilka uwag o kancelarii królewskiej w drugiej połowie XVI wieku, „Archeion", t. 37, 1962, s. 235-252.

${ }^{3}$ W. Krawczuk, Pisarze kancelarii koronnych Zygmunta III Wazy, „Studia Historyczne”, r. 36, 1993, z. 2, s. 149-164; id, Metrykanci koronni. Rozwój registratury centralnej od XVI do XVIII wieku, Kraków 2002. Duże znaczenie mają również studia poświęcone sekretarzom królewskim, których część uczestniczyła w sporządzaniu różnego rodzaju dokumentów i pism, przede wszystkim A. Wyczańskiego, Między kulturq i politykq. Sekretarze królewscy Zygmunta Starego (1506-1548), Warszawa 1990; L. Kieniewicza, Sekretariat Stefana Batorego. Zbiorowość i kariery sekretarzy królewskich, [w:] Spoteczeństwo staropolskie, t. IV, pod red. A. Izydorczyk i A. Wyczańskiego, Warszawa 1986, s. 33-69; M. Korolki, Seminarium Rzeczypospolitej Królestwa Polskiego. Humaniści w kancelarii królewskiej Zygmunta Augusta, Warszawa 1991.

${ }^{4}$ I. Sułkowska-Kurasiowa, J. Wejchertowa, Księgi Poselskie (Libri Legationum) Metryki Koronnej, „Archeion”, t. 48, 1968, s. 61-73; I. Sułkowska-Kurasiowa, Księgi Sigillat Metryki Koronnej (1658-1794), Ibid., t. 54, 1970, s. 41-57; ead, Księgi Kanclerskie (Księgi Spraw Publicznych) Metryki Koronnej, Ibid., t. 60, 1974, s. 143-158. 
ze studiami nad kancelarią Zygmunta Starego podjętymi przez W. Chorążyczewskiego. Autor ten dokonał wstępnych szacunków procentowych dokumentacji wojskowej powstającej w kancelarii Zygmunta Starego ${ }^{5}$. Ponadto wstępnie scharakteryzował dokumenty tego monarchy dotyczące spraw wojskowych, a wśród nich uniwersały mobilizacyjne (tzw. wici) oraz ustalił ich ilość ${ }^{6}$. Odczuwa się również wielki niedostatek edycji źródłowych, których brak częściowo wypełniają kodeksy dyplomatyczne większych miast, zawierające sporo dokumentów królewskich.

Ogrom zachowanych a rozproszonych źródeł zniechęca badaczy do podejmowania śmielszych prób. A czynić to należy, bowiem pogłębia się dysproporcja między wiedzą o produkcji kancelaryjnej centralnych organów państwa a znajomością dokumentacji urzędów ziemskich czy też miejskich i to zupełnie małych niekiedy ośrodków. Sytuacja taka może deformować pogląd na wiele istotnych kwestii i to nie tylko ściśle dyplomatycznych, ale politycznych czy prawnych.

Niedostatek szerszych badań częściowo powinny rekompensować analizy poszczególnych rodzajów dokumentacji czy typów dokumentów wytwarzanych w kancelarii królewskiej. Mam nadzieję, że ta siłą rzeczy wstępna analiza będzie krokiem w tym właśnie kierunku.

Treść nazwy uniwersał przejętej ze staropolskiej, terminologii urzędowej, nie została do tej pory precyzyjnie określona. Ale funkcjonujące dotychczas określenie jako aktu normatywnego, wydawanego przez władcę, jest nieprzypadkowo ogólnikowe. Jego autor na pewno miał świadomość wielkiej różnorodności dokumentów i pism, określanych tym mianem. Wieloznaczność tego terminu powinna skłaniać do podjęcia próby opisu znaczeń w których był używany. Dodatkowy powód zainteresowania tego rodzaju dokumentem stanowiło szerokie jego rozpowszechnienie, uzasadniające zaliczenie go w poczet podstawowych produktów kancelarii królewskiej okresu staropolskiego. Uniwersałami bowiem posługiwali się nie tylko monarchowie i prymasi pełniący funkcje interrexa, ale też liczni urzędnicy, przede wszystkim ministrowie, hetmani, a także wojewodowie i kasztelani. Z licznych typów dokumentów sporządzanych w kancelarii królewskiej na uwagę zasługują te związane ze sprawami wojskowymi, w tym także służące do zwoływania pospolitego ruszenia.

Podstawę źródłową tego referatu stanowią uniwersały oblatowane w aktach grodzkich chełmskich. Wybór tego grodu nie wynikał z teoretycznych przesłanek, ale spowodowany był wcześniejszą kwerendą w ramach badań nad produkcją aktową tamtejszej kancelarii grodzkiej. Ze względu na cel referatu i jego

${ }^{5}$ W. Chorążyczewski, Nowożytny dokument królewski. Możliwości badawcze, [w:] Polska kancelaria królewska czasów nowożytnych. Między wtadzq a spoteczeństwem. Materiaty z konferencji naukowej, Toruń 18 kwietnia 2002 roku, Toruń 2003, s. 47-48.

${ }^{6}$ Id., Sprawy wojskowe w kancelarii królewskiej Zygmunta Starego, ,,Miscellanea HistoricoArchivistica" t. 13, 2001, s. 72-74.

${ }^{7}$ S. Kutrzeba, Historia źródet dawnego prawa polskiego, t. I, Lwów 1926, s. 200. 
charakter, wybór grodu miał znaczenie drugorzędne. Chodzi w nim bowiem o formułowanie pytań i raczej hipotetyczne próby odpowiedzi na nie, niż o definitywne rozstrzygnięcia sygnalizowanych problemów.

Wśród uniwersałów odnoszących się do spraw wojskowych pod względem ilościowym na czoło wysuwają się te, które można określić mianem mobilizacyjnych. Miały one umożliwić przygotowanie do udziału w walce pospolitego ruszenia, które w ówczesnym systemie obronnym Rzeczypospolitej odgrywało jeszcze pewną rolę. Ciężar obrony ówczesnego państwa spoczywał na oddziałach zaciężnych: wojsku kwarcianym, suplementowym (od r. 1652 obie te formacje połączono w tzw. wojsko komputowe) czy rejestrowym wojsku zaporoskim (istniejącym tylko do 1648 r. $)^{8}$, które stanowiły daleko pewniejszą i skuteczniejszą siłę. Jednak w sytuacji zagrożenia całego państwa, konieczne było wsparcie ze strony oddziałów dymowych i łanowych, skupiających chłopskich rekrutów, powoływanych proporcjonalnie do ilości dymów bądź łanów oraz wojsk prywatnych i ordynackich ${ }^{9}$. Przydawały się wtedy również chorągwie sformowane z powołanej pod broń szlachty.

Pospolite ruszenie, stanowiące najstarszą formację wojskowa, wywodzącą się jeszcze $\mathrm{z}$ okresu wczesnośredniowiecznego, skupiało szlachtę posiadająca bądź użytkującą ziemię. Obejmowało więc zarówno właścicieli jak i dzierżawców czy zastawników, a nawet wyderkarzy. ${ }^{10}$ Musieli się na nie stawić również nieszlacheccy posiadacze ziemi (np. duchowni) przez swoich zastępców, szlachta nieosiadła ${ }^{11}$, oraz wójtowie i sołtysi, zobowiązani do tego przywilejami lokacyjnymi, a także wybrańcy. Na miastach królewskich ciążył obowiązek dostarczania wozów $\mathrm{z}$ odpowiednim wyposażeniem wojennym (proch, kule, a nawet broń palna) oraz żywnością. Zwoływał je król za zgodą sejmików i sejmu, co gwarantował jeszcze przywilej nieszawski. Upoważnienie, które otrzymywał król na sejmie posiadało charakter jednorazowy i jeśli na kolejnym sejmie nie zostało prolongowane traciło swoją $\operatorname{moc}^{12}$. Szczegółowe kwestie związane $z$ organizacją pospolitego ruszenia uregulowała konstytucja sejmowa z r. 1621, wydana po klęsce cecorskiej w obliczu realnego zagrożenia tureckiego ${ }^{13}$.

${ }^{8}$ Zarys dziejów wojskowości polskiej do r. 1864, t. II, red. J. Sikorski, s. 21-22; J. Wimmer, Wojsko. [w:] Polska XVII wieku. Państwo - spoteczeństwo - kultura, pod red. J. Tazbira, Warszawa 1974 , s. $178-183$.

${ }^{9}$ Zarys dziejów wojskowości..., t. II, s. 22.

${ }^{10}$ Volumina Legum (dalej: VL), wyd. J. Ohryzko, t. III, Petersburg 1859, nr 416, 417; A. Pawiński, Rzqdy sejmikowe w Polsce 1572-1795 na tle stosunków województw kujawskich, oprac. H. Olszewski, Warszawa 1978, s. 357

\footnotetext{
${ }^{11} \mathrm{VL}, \mathrm{t}$. III, f. 416, 417.

${ }_{12}^{12}$ A. Pawiński, op. cit., s. 367

3 Ibid., s. 356.
} 
Wartość bojowa pospolitego ruszenia w zgodnej opinii historyków nie była na ogół wielka. Ale podkreśla się, że w okresie potopu szwedzkiego po początkowych klęskach (Ujście - 1655 r.) okrzepło i dobrze sobie radziło w walce ze Szwedami. W XVII w. pospolite ruszenie niezbyt często brało jednak udział w walce. Jako siła zbrojna, oprócz wspomnianego okresu 1655-1657, zaledwie kilka razy starło się z przeciwnikiem (w $1.1621,1649,1672)^{14}$. Bez względu na jego rzeczywistą wartość bojową i znaczenie militarne, stanowiło element systemu obronnego, umożliwiający szlachcie spełnienie prawnej i ideowej powinności obrony Rzeczypospolitej.

Uniwersały królewskie, na podstawie których mobilizowano szlachtę zwano wiciami ${ }^{15}$, od starosłowiańskiego systemu powiadamiania o niebezpieczeństwie przy pomocy zapalonych wiązek słomy, wici, przekazywanych od wsi do wsi. Ich treść ogłaszano w grodach, miastach i parafiach. Czynili to zwykle woźni sądowi lub słudzy miejscy, w miejscach ogólnie dostępnych i uczęszczanych, w porach największej obecności. Najbardziej nadawały się do tego rynki miast, często odwiedzane w dni targowe. Za upowszechnienie treści uniwersałów w parafiach odpowiedzialni byli proboszczowie. Obowiązek wpisania uniwersałów do akt urzędowych ciążył na kancelariach grodzkich, również one dokumentowały publikację uniwersałów oraz rozsyłały je w teren ${ }^{16}$.

Wici dzieliły się na trzy rodzaje, zależnie od kolejności ich wydania. Praktycznie dopiero tzw. trzecie wici pociągały za sobą konieczność wyruszenia szlachty na wyprawę wojenną. Wcześniejsze oznaczały określony, zwykle wstępny, stopień gotowości wojennej.

W pierwszych wiciach król bardziej lub mniej szczegółowo charakteryzował niebezpieczeństwo militarne i polecał rozpoczęcie przygotowań do wojny. Nie precyzował w nich czynności, które szlachta miała wykonać. Nakazywał jedynie, by była gotowa do stawienia się pod komendę hetmanów lub wojewodów, w terminie określonym w późniejszych uniwersałach ${ }^{17}$. Zdarzało się czasem, że w sposób ogólny przypominano urzędnikom ziemskim, odpowiedzialnym za kierowanie pospolitym ruszeniem (wojewodom i kasztelanom) o ich powinnościach ${ }^{18}$. Ogólnikowość formuł traktujących o obowiązkach szlachty wskazuje, że nie było potrzeby ich precyzowania, bowiem w XVII w. wiedziała ona jak należy się przygotować do wyprawy wojennej. Jakkolwiek pierwsze wici nie oznaczały jeszcze wojny, to zobowiązywały szlachtę do rozpoczęcia

${ }^{14}$ Zarys dziejów wojskowości..., s. 26.

15 Stownik Staropolski, t. 8, Kraków 1988-1993, s. 111; K. Hahn, Pospolite ruszenie wedle uchwat sejmikowych ruskich od XVI do XVIII w., „Pamiętnik Historyczno-Prawny”, t. 6, 1928, z. 4, s. 46.

${ }^{16}$ Archiwum Państwowe w Lublinie (dalej cyt.: APL), Akta grodzkie chełmskie (dalej cyt.: agch), Relationes, manifestationes, oblatae (dalej cyt.: RMO), sygn. 74, k. 1210v (laudum sejmiku chełmskiego z 2 X 1656 r.).

${ }^{17}$ lbid., k. 138v - uniwersał Jana Kazimierza z 9 IV 1652 r.

${ }^{18}$ Nacyjanalny Gistaryčny Archiǔ Belarusi w Mińsku (dalej cyt.: NGAB), fond (dalej: f.) 1740, opis (dalej: op.) 1, edinica (dalej: ed.) 4, k. 178-179v. 
przygotowań militarnych i uregulowania wszelkich spraw natury pozawojskowej: prawnych, gospodarczych i rodzinnych.

Uniwersały, określane mianem drugich wici, różniły się od pierwszych jedynie nazwą. Potwierdzały obowiązek kontynuowania przygotowań do wyprawy wojennej, zapowiadając niekiedy wydanie trzecich wici ${ }^{19}$, oznaczających rychły wymarsz na wojnę. Zdarzało się też, że zawierały również bardziej szczegółowe polecenia. Drugie wici z 30 XII 1666 r. nakazywały urzędnikom miejskim (wójtom i burmistrzom) przygotowanie w miastach odpowiednich zapasów żywności $i^{20}$.

Istniała możliwość skrócenia trybu przygotowywania pospolitego ruszenia przez łączne wydanie pierwszych i drugich wici w postaci jednego uniwersału ${ }^{21}$. Podwyższony stan gotowości wojennej szlachty, używając współczesnej terminologii, wprowadzony przez drugie wici można było odwołać ${ }^{22}$.

W ostatnich trzecich wiciach określano termin stawiennictwa szlachty na sejmik poprzedzający pospolite ruszenie ${ }^{23}$. Dokonywano na nim obioru rotmistrzów oraz oznaczano termin i miejsce pospolitego ruszenia ziemi i województwa. W tej sprawie zwykle własny uniwersał wydawał kasztelan lub najwyższy po nim urzędnik ziemski, po to by właściwa informacja dotarła do tych, którzy byli nieobecni na sejmiku ${ }^{24}$. Dokument ten publikowano w trybie podobnym do uniwersałów królewskich i tak jak i inne tego typu dokumenty oblatowano w grodzie ${ }^{25}$.

Zdarzało się jednak, że nie podawano terminu zjazdu szlachty. W roku 1614 król Zygmunt III Waza poprzestał jedynie na poleceniu, by adresaci uniwersału stanęli przy nim, nie określając bliżej miejsca ${ }^{26}$. W uniwersale z 13 VII $1650 \mathrm{r}$. król Jan Kazimierz nakazał ogólnikowo stawienie się przed wojewodami bądź kasztelanami ${ }^{27}$. W obu tych przypadkach szlachta musiała więc czekać, aż stosowne rozporządzenia wydadzą lokalni urzędnicy ziemscy.

Powoływanie pospolitego ruszenia było procesem skomplikowanym i długotrwałym. Od momentu wysłania pierwszych wici aż do wyruszenia wojska na wyprawę mijało nie mniej niż 6-7 miesięcy ${ }^{28}$. Dlatego starano się uprościć pro-

${ }^{19}$ Ibid., k. 638-638v (uniwersał Zygmunta III Wazy z 23 V 1621 r.); ed. 14, k. 8v-9 (30 XII 1666 r.); APL, Agch, RMO, sygn. 74, k. 128-138v (9 VI 1652 r.).

${ }^{20} \mathrm{NGAB}, \mathrm{f} .1740$, op. 1 , ed. $14, \mathrm{k} .8 \mathrm{v}-9$.

${ }^{21}$ W konstytucji sejmowej z r. 1619 stwierdzono: „... i gdyby nie mogło bydź inaczej tedy pierwsze wici za dwoje wydać i rozesłać (z drugiemi dalszej a ostatniej wiadomości i rezolucyi czekając) rozkażemy...”. VL, t. III, 352.

1564 r.)

APL, Agch, Decreta, sygn. 1, k. 378 (,Reportacio restium per ministerialem” - 14 VI

${ }^{23}$ K. Hahn, Pospolite ruszenie..., s. 46.

${ }^{24}$ lbid.

${ }^{25}$ Ibid.

${ }^{26}$ APL, Agch, Inscriptiones, sygn. 17, k. 423-424. Wydany został $23 \mathrm{~V}$ tego roku.

${ }_{28}^{27}$ NGAB, f. 1740 , op. 1 , ed. 6 , k. 366v.

${ }^{28}$ A. Pawiński, Dzieje ziemi kujawskiej..., s. 368. 
cedurę wydawania wici. I tak w czasie oblężenia króla Jana III Sobieskiego i dowodzonych przez niego wojsk polskich w obozie warownym pod Żórawnem w październiku $1676 \mathrm{r}$. wici, bez określania numeru, wydał niejako w jego zastępstwie prymas Andrzej Olszowski ${ }^{29}$. Dokument ten adresowano zarówno do szlachty, jak i oddziałów wojskowych. Przedstawiono w nim dość szczegółowy opis wydarzeń, które doprowadziły do opresji królewskiej. Dyspozycja uniwersału pozbawiona była jednak konkretów, co może wskazywać na to, że jego zadanie bardziej polegało na przygotowaniu odbiorców do wojny niż skierowaniu działań wojska w określonym kierunku ${ }^{30}$. Szlachcie polecono bowiem skupienie się przy wojewodach i kasztelanach, składając na ich barki odpowiedzialność za dalszy przebieg organizacji wyprawy.

Obok wici występowały również inne typy uniwersałów, które odnosiły się do spraw militarnych. Zwykle dokumenty te informowały o niebezpieczeństwie, nie przynosząc jednak ściślej określonego polecenia, poza wezwaniem do czujności i gotowości do obrony. Przykładem może być uniwersał króla Zygmunta III Wazy z 20 IX 1618 roku, ostrzegający przed najazdem tatarskim ${ }^{31}$. Z późniejszych wymienić można uniwersał wydany przez króla Jana Kazimierza 1 IX 1667 r., powiadamiający o niebezpieczeństwie tureckim ${ }^{32}$.

Od wymienionych dokumentów wyraźnie odróżniają się uniwersały, które nie tylko przestrzegały przed zagrożeniem militarnym, ale również zachęcały szlachtę do wzięcia udziału w wojnie. Wobec silnego zagrożenia tatarskiego król Zygmunt III Waza w swym uniwersale z 8 VI 1618 r. nakłaniał szlachtę od wstępowania w szeregi wojska walczącego na Ukrainie „bądź osobami bądź pocztami, przykładem przodków swych"33. Podobnemu celowi służyły wezwania królewskie wydawane dwa lata później. W uniwersale z 16 VII 1620 r. król wzywał do rozprawy z wojskami turecko-tatarskimi u boku hetmana wielkiego koronnego Stanisława Żółkiewskiego ${ }^{34}$.

Po bitwie pod Cecorą 8 X 1620 r. król nie mając jeszcze informacji o rozbiciu oddziałów polskich i śmierci hetmana, świadomy powagi sytuacji, starał się pokrzepić szlachtę wieściami, że wojsko nadal broni się w obozie ${ }^{35}$. Apelowa-

${ }^{29}$ APL, Agch, RMO, sygn. 95, k. 522-524. Datowano je na 15 X.

${ }^{30}$ Nakazywał by „tułające się po województwach regimenty i znaki braterskie” jak najprędzej „... tam biegli, gdzie ich żołnierska pociąga vocatia, aby przynajmniej za tak nieznośne przeciagi i wyniszczenia ojczyzny to dali afficitis rebus solatium, że nas inter discrimini principis et comilitonum non deseruit...”. Ibid.

${ }^{31}$,.... Uprzejmości i Wierności Wasze żebyście przez ten czas, póki jakakolwiek s tym poganinem [Tatarami - JŁ.] rosprawa nie bendzie, ostrożnie w majętnościach i domach swoich siedzieli i pilnie na to oko mieli, aby za prędkim, czego strzeż Panie Boże, tatarskim spadaniem, które tamże in pridem temu poganinowi leda jakto bez wszelakiej obrony i ostrożności nie przychodzili...”. APL, Agch, Zapisy, sygn. 18, k. 348-348v.

\footnotetext{
${ }^{32}$ NGAB, f. 1740 , op. 1 , ed. 14 , k. 303-304v.

${ }^{33}$ APL, Agch, Inscriptiones, sygn. 18, k. 254-254v.

${ }^{34} \mathrm{NGAB}$, f. 1740 , op. 1 , ed. 4 , k. $247 \mathrm{v}-248$.

${ }^{35}$ Ibid., k. 327-327v.
} 
nie, by szlachta kierowała się ku granicom wołoskim i ratowała osaczone wojsko, odzwierciedlało faktyczną bezsilność władcy, który nie był w stanie przyjść oddziałom hetmańskim z jakąkolwiek pomocą. Pod wrażeniem wieści o klęsce, $11 \mathrm{X}$ król skierował kolejny uniwersał, w którym usprawiedliwiając wyprawę, podnosił męstwo żołnierzy i usprawiedliwiał klęskę wyrokiem boskim ${ }^{36}$. Prosił, by wszyscy należący do stanu rycerskiego, w trosce o ratunek dla tonącej ojczyzny gromadzili się i ,na posiłek bieżali, ${ }^{37}$.

Wspomniane uniwersały nie miały charakteru wici, bowiem gwałtowne zagrożenie, pod wpływem którego publikowano królewskie wezwanie, raczej wykluczało celowość rozkręcania powolnej machiny pospolitego ruszenia. Efektywną pomoc mogła okazać jedynie szlachta, mobilizująca się indywidualnie i oczywiście dostatecznie sprawnie. Z prawnego punktu widzenia nie była ona zobowiązana do udziału w walce i mogła zlekceważyć prośby króla.

W uniwersałach mobilizacyjnych kierowanych do szlachty nie zawsze wspominano o wybrańcach. Z różnych przyczyn ich liczebność nie osiagała spodziewanego poziomu ${ }^{38}$. Z jednej strony pobór wybrańców utrudniali dzierżawcy i starostowie, na barki których spadał obowiązek utrzymania rodzin powołanych pod broń i uprawy użytkowanej przez nich ziemi. Z drugiej zaś sami rotmistrze, nielegalnie, za odpowiednią opłatą zwalniali chłopów zdolnych do służby wojskowej. Dlatego w celu usprawnienia poboru wybrańców król wydawał osobne uniwersały, bądź czynili to za niego hetmani ${ }^{39}$. Dokumenty te ze względu na ograniczone ramy referatu nie będą przedmiotem zainteresowania, chociaż również zasługują na uwagę.

Spośród uniwersałów królewskich, których odbiorcą była ziemia chełmska, warto wspomnieć dokument wydany przez króla Zygmunta III Wazę 15 III 1623 r., upoważniający rotmistrza Michała Ładę do mobilizacji wybrańców z terenu województw ruskiego i podolskiego oraz stawienia się trzy miesiące później ( 15 V 1623 r.) z gotowymi do działań oddziałami ${ }^{40}$. Przypadek tego uniwersału wskazuje, że samo okazanie przez rotmistrza listu przypowiedniego i jego oblatowanie w grodzie nie stanowiło dostatecznej gwarancji udanej mobilizacji rekrutów. Ułatwiać ją miała odezwa królewska, przygotowująca starostów, urzędy grodzkie oraz dzierżawców do akcji poborowej. Czy rzeczywiście spełniła swoją rolę - trudno dociec. Można jedynie przypuszczać, że jej wydanie chyba lepiej przygotowało grunt do tej niełatwej operacji.

Do spraw mobilizacyjnych odnosi się również uniwersał króla Jana III Sobieskiego, datowany na 24 XII 1685 r., obciążający wszystkich nobilitowanych i indygenowanych po $1656 \mathrm{r}$. obowiązkiem wystawienia osobnych pocztów. Składać się one miały z trzech koni husarskich z pełnym oporządzeniem i kwotą

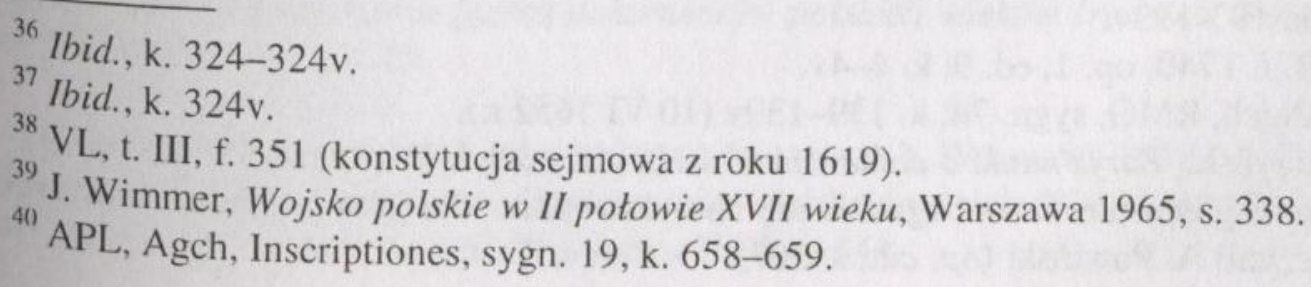


pieniędzy na żołd i utrzymanie lub opłacenia ekwiwalentu pieniężnego w kwocie 5 tys. złotych ${ }^{41}$.

Charakterystyczne, że za pomocą uniwersału wystawionego 17 VI 1652 r. król Jan Kazimierz łagodnie „napominał” podstolego koronnego Mikołaja Daniłowicza do zaopatrzenia zamku w Uchaniach, tak by stanowił ważny punkt obrony przed Kozakami i Tatarami ${ }^{42}$, obiecując jednocześnie pokrycie wszelkich związanych z tym kosztów.

Jednak wiele uniwersałów redagowano w formie stanowczych zarządzeń. Na uwagę zasługuje tu przede wszystkim dokument króla Jana Kazimierza z 12 VII 1652 r. Wydany został dla przeciwdziałania rozprzężeniu panującemu w wojsku. Powodowali je oficerowie samowolnie opuszczający powierzone im oddziały, co stawało się przyczyną dezercji żołnierzy. Ponowne zaciąganie się dezerterów do innych chorągwi pogłębiało chaos organizacyjny, spowodowany opuszczaniem oddziałów ${ }^{43}$.

Podobny charakter posiadają również wcześniejsze uniwersały króla Zygmunta III Wazy. Dokumentem z dnia 13 III 1609 r. nakazał on zwalczanie „kup swawolnych", napadających na pograniczne ziemie należące do Turcji, lub pozostające pod jej protektoratem. Łamanie przez swawolników, głównie Kozaków, podpisanych przez Rzeczypospolitą porozumień narażało państwo na poważne niebezpieczeństwo odwetowego najazdu tureckiego ${ }^{44}$.

Za pośrednictwem uniwersału król Jan Kazimierz poinformował szlachtę o przekazaniu w ręce wojewody podolskiego Stanisława „Rewery” Potockiego kompetencji naczelnego dowódcy wojsk walczących na Ukrainie, po pamiętnej klęsce oddziałów polskich pod Batohem i śmierci hetmana Kalinowskiego ${ }^{45}$.

* $\quad * \quad *$

Dokonany przegląd uniwersałów uwidacznia znaczną ich różnorodność, zarówno treściową jak i prawną, a co za tym idzie - również dyplomatyczną. Większość z nich to typowe dokumenty (w węższym znaczeniu), za które tradycyjnie uważa się pisemne oświadczenia, sporządzone według pewnych określonych lub zmieniających się zależnie od osoby, miejsca, czasu i treści form, które służyły jako świadectwa faktów natury prawnej ${ }^{46}$. Takimi są niewątpliwie wici, dostarczające podstawy prawnej przejścia szlachty $\mathrm{z}$ okresu pokojowego do stanu gotowości, a potem mobilizujące ją do wojska ${ }^{47}$. Podobnie rzecz się ma z

\footnotetext{
${ }^{41}$ Ibid., RMO, sygn. 107, k. 130-131v.

${ }^{42}$ Ibid., sygn. 74, k. 174-175v.

${ }^{43}$ Ibid., k. 193-193v.

${ }^{44}$ NGAB, f. 1740 , op. 1, ed. 9, k. 4-4v.

${ }^{45}$ APL, Agch, RMO, sygn. 74, k. 139-139v (10 VI 1652 r.).

${ }^{46}$ S. Kętrzyński, Zarys nauki o dokumencie wieków średnich, Warszawa 1934, s. 49, 52-54.

${ }^{47} \mathrm{Z}$ tego względu nie można zgodzić się na traktowanie wici jako „wojennych listów okolnych", jak to czynił A. Pawiński (op. cit., s. 367).
} 
uniwersałami, na podstawie których powoływano inne kategorie osoby zobowiązane do służby wojskowej (wybrańcy, sołtysi, nobilitowani i indygenowani).

Do dokumentów zaliczyć można też uniwersały w postaci mandatów. Były to zazwyczaj polecenia skierowane przez władcę do jego urzędników lub innych osób, zlecające im wykonanie określonych czynności prawnych ${ }^{48}$. Ich cechami konstytutywnymi były: stosunkowo zawężony krąg odbiorców (jedna osoba lub ściśle określona grupa) oraz wyraźne polecenie do wykonania. Zwolennikiem takiego stanowiska był wcześniej S. Kętrzyński, choć niektórzy badacze zaliczali mandaty do listów ${ }^{49}$. Argumentacja wyżej cytowanego autora wydaje się bardziej przekonująca. Twierdził on, że mandat każdorazowo można uznać za świadectwo faktu natury prawnej, którym była wola wystawcy ${ }^{50}$.

Istniała jednak osobna grupa uniwersałów, niezawierających wyraźnych poleceń, w których funkcja informacyjna przeważała nad dyrektywną. Zaliczyć można do nich te, które ostrzegały o militarnym niebezpieczeństwie, nienakazując jednak podejmowania określonych działań. Nie wprowadzały one nowego stanu prawnego ani też nie poświadczały stanu prawnego istniejącego przedtem. Zbliżone są więc do listów, którymi w dyplomatyce określa się zwykle pisma zredagowane na podobieństwo dokumentu, skierowane do pewnej ściśle określonej osoby, a zawierające wiadomości o dokonanej czynności prawnej, o charakterze politycznym czy majątkowym, mogące służyć powstawaniu i wykonywaniu uprawnień $^{51}$. Od typowych listów odróżnia je jednak zbiorowy, a nie indywidualny adresat. Bardziej przypominają więc współczesne odezwy.

Oczywiście takiego zróżnicowania nie dostrzegano w okresie, w którym wykorzystywano uniwersały. Rozróżnienie przedstawione wyżej pozwala na lepsze poznanie różnorodnej dokumentacji określanej tym mianem. Rozpowszechnienie się uniwersałów jako specyficznego produktu kancelaryjnego, wykazującego szeroką użyteczność w różnych sferach, a więc polityce, gospodarce czy kręgu spraw społecznych, powinno skłaniać badaczy do poważniejszego zainteresowania jego geneza, a także znaczeniem na tle produkcji aktowej kancelarii królewskiej, o której w dalszym ciągu, mimo systematycznego postępu, wiemy zbyt mało.

* * * $\quad *$

48 J. Szymański, op. cit., s. 444. Cytowany autor traktuje mandaty jako rodzaj listów. Jako osobną kategorię dyplomatyczną wyodrębniają je: K. Maleczyński, M. Bielińska, A. Gąsiorowski, op. cit., s. 20 .

${ }^{49}$ S. Kętrzyński, Zarys nauki o dokumencie polskim wieków średnich, Warszawa 1934, s. 54. Za rodzaj listu uważają mandaty A. Gieysztor, op. cit., s. 71; J. Szymański, op. cit., s. 444; G. Klimecka, Z historii tworzenia języka dokumentów polskich wieków średnich. Formularz ciechanowski, Warszawa 1997, s. 25.

${ }_{51}^{50}$ S. Kętrzyński, op. cit.

A. Gieysztor, Zarys nauk pomocniczych historii, t. 1, Warszawa 1948, s. 71; K. Maleczyński, M. Bielińska, A. Gąsiorowski, Dyplomatyka wieków średnich, Warszawa 1971, s. 20; J. Szymański, Nauki pomocnicze historii, Warszawa 2002, s. 444. 
Pod względem budowy wewnętrznej uniwersały częściowo przypominają schemat dokumentu średniowiecznego. Upodabniały je do niego zarówno układ treści, z trzema częściami stałymi: protokołem, kontekstem i eschatokołem, jak i treść niektórych formuł.

Protokół zawsze zaczynał się pełną intytulacją, wzbogaconą formułą dewocyjną ${ }^{52}$. W przypadku królów z dynastii Wazów aż do roku 1660 podkreślano ich prawa do tronu szwedzkiego, informując że są dziedzicznymi królami szwedzkimi, gockimi i wandalskimi ${ }^{53}$.

Inskrypcja, czyli określenie odbiorcy z reguły połączona była z promulgacją, a więc określeniem woli wystawcy do wystawienia dokumentu i zróżnicowana była w zależności od adresata uniwersału. Najczęściej pojawiał się schemat informacyjny uwzględniający społeczne zróżnicowanie odbiorców. Wymieniano więc poszczególne ich warstwy, począwszy od stojących najwyżej w hierarchii społecznej senatorów, poprzez dygnitarzy, urzędników, skończywszy na zwykłych obywatelach całej Rzeczypospolitej, ziemi czy województwa ${ }^{54}$. Taki zestaw uzupełniano niekiedy o urzędników, wymienianych osobno, jak starostów czy ich namiestników ${ }^{55}$. Zbitkę tych dwóch formuł uzupełniano jeszcze salutacja, zwrotem grzecznościowym, podkreślającym wierność szlacheckich poddanych wobec króla, odwzajemnianą przez niego ${ }^{56}$.

Drugą część dokumentu otwierała narracja, czyli opis okoliczności towarzyszących wystawieniu, zmuszających króla do określonych działań. Niekiedy rozpoczynał ją powtarzany zwrot grzecznościowy ${ }^{57}$, znany z salutacji, upodobniający uniwersał do listów. W uniwersałach odnoszących się do spraw militarnych zwykle zawierała ona bardziej lub mniej szczegółową charakterystykę sytuacji politycznej, uzupełnianą o niezbędne szczegóły, dające wyobrażenie o skali zbrojnego zagrożenia. Czasem ujawniano w nich źródła, z których pochodziły otrzymane przez króla wieści.

W uniwersale z 23 V 1614 r. wprost wskazywano na „strażników i urzędników wojennych" w dalszej części wymieniając dalej osoby hetmana wielkiego koronnego Stanisława Żółkiewskiego, oraz wojewody kijowskiego ${ }^{58}$, zapewne po to, by dodatkowo gwarantować wiarygodność informacji. W dokumencie $\mathrm{z}$ 14 V 1620 r. wskazano, że informacje o zagrożeniu tureckim pochodzą od posła

${ }^{52}$ Np. ,Zygmunt III z Bożej Łaski król Polski, Wielkie Xsiqżę Litewskie, Ruskie, Pruskie, Mazowieckie, Żmudzkie, Inflantskie”. APL, Agch, Inscriptines, sygn. 14, k. 604 (8 VI 1605 r.).

${ }^{53} \mathrm{~Np} .$, , $i$ Szwedski, Gotski, Wandalski dziedziczny król’. Ibid.

${ }^{54} \mathrm{~Np}$. „Wszem wobec $i$ każdemu z osobna komu to wiedzieć będzie należato a mianowicie senatorom, dygnitarzom, urzędnikom $i$ wszystkim stanu rycerskiego powotania ludziom tej zacnej Rzeczypospolitej Królestwa Polskiego i państw do niego przynależnych obywateli”. Ibid., sygn. 18 , k. 254 (8 VI 1618 r.).

\footnotetext{
${ }^{55}$ Ibid., sygn. 17 k. 411 v (24 IV 1614 r.); syg 14, k. 604 (8 VI 1605 r.).

${ }^{56} \mathrm{~Np}$. ,uprzejmie $i$ wiernie nam mitym”. Ibid., sygn. 17, k. 411 (26 IV1614 r.).

57 „Uprzejmie i wiernie nam mili”. Ibid., RMO, sygn. 74, s. 144v (14 VI 1652 r.).

${ }^{58}$ Ibid., Inscriptiones, sygn. 17, k. 423-424.
} 
królewskiego Hieronima Otwinowskiego, który wysłany został z misją do Konstantynopola $^{59}$. Jednak określenie okoliczności fiaska jego działań spowodowane było innymi przyczynami, o czym jeszcze będzie mowa. Wzmianka o informacjach uzyskanych od generalnego starosty podolskiego Mikołaja Potockiego oraz jeńców tureckich znalazła się w uniwersale Michała Korybuta Wiśniowieckiego ${ }^{60}$.

Często formułę tą nasycano argumentami retorycznymi o znaczeniu propagandowym, mającymi na celu przekonanie odbiorcy szlacheckiego do królewskich racji i rozwiewania wątpliwości, które mogłyby osłabiać u szlachty wolę walki. Więcej informacji na ten temat znajduje się w dalszej części referatu.

Druga formuła kontekstu, dyspozycja określająca sposób działania adresatów, została już scharakteryzowana wcześniej. Na tle rozbudowanej narracji uderzać może ogólnikowość dyspozycji. Jeśli uznamy ją za rzecz naturalną przy wiciach, to w uniwersałach nie będących formalnymi nakazami podwyższania gotowości bojowej ale wezwaniami do walki ogólnikowość poleceń może dziwić. Pamiętać jednak należy, że król raczej nie dowodził bezpośrednio całą armią, składając ten obowiązek na barki hetmanów. Natomiast szlachtą, aż do momentu połączenia $\mathrm{z}$ wojskiem hetmańskim, samodzielnie dowodzili lokalni kasztelanowie, wojewodowie lub inni wyżsi urzędnicy ziemscy i to ich uniwersały zawierały konkretne polecenia.

Trzecia formuła kontekstu, którą była koroboracja, występowała rzadko. Tradycyjnie zapowiadała sposób uwierzytelnienia ${ }^{61}$. Kontekst kończyło zwykle polecenie aktykacji uniwersału w aktach grodzkich oraz jego publikacji ${ }^{62}$. W niektórych dokumentach stosowano jej rozszerzoną wersję, w której wyliczano miejsca, w których miano ogłaszać jego treść, a więc grodach miastach, miasteczkach oraz parafiach ${ }^{63}$.

Część końcowa dokumentów (eschtokół) przedstawiała się skromnie. Otwierała ją datacja, określając miejsce i datę wystawienia dokumentu, która podawana była przez cały XVII wiek już według kalendarza nowożytnego, co kontrastowało ze zwyczajami oblatujących uniwersały kancelarii grodzkich, w których niemal aż upadku Rzeczypospolitej posługiwano się kalendarzem chrześcijańskim. Formułę wzbogacało również określenie roku panowania władcy. W przypadku monarchów z dynastii Wazów obejmowała także określenie okresu panowania na tronie szwedzkim, odzwierciedlające ich niewygasłe aspiracje polityczne w tym kierunku.

${ }^{59} \mathrm{NGAB}$, f. 1740 , op. 1 , ed. 4 , k. $178-179$ v.

${ }_{61}^{60}$ APL, Agch, RMO, sygn. 91, k. 320-320v (23 VIII 1672 r.).

${ }^{61}$ „Na co dla lepszej wiary przy podpisie ręki naszej królewskiej pieczęć koronna przycisnać rozkazaliśmy". Ibid., sygn. 91, s. 88 (27 II 1672). Zob. niewiele zmienione wersje, s. 272 (5 VII 1672), 320 (23 VIII 1672).

${ }^{62} \mathrm{~Np} .$, ,który uniwersat,

akta wpisawszy publikowali”. aby do wiadomości wszystkich przysc mógt rozkazujemy, aby go w

${ }^{63}$ Ibid., RMO, sygnali”. Ibid., Inscriptiones, sygn. 20, k. 217 (15 VI 1626 r.).

Ibid., RMO, sygn. 74, s. 138v (9 VI 1652 r.), 145v (14 VI 1652 r.). 
Zestaw środków uwierzytelnienia był skromny. Tworzyły go pieczęć koronna oraz podpis króla. Podpis sekretarza lub regenta kancelarii ${ }^{64}$ miał prawdopodobnie znaczenie kancelaryjne i wskazywał na ich czynny udział w tworzeniu konceptów dokumentów. Dyktat uniwersałów stanowił raczej ich wytwór. Czy również treść dokumentów stanowiła wyłącznie ich dzieło trudno rozstrzygać w sposób zdecydowany, bowiem nie pozwala na to stan wiedzy o siedemnastowiecznej kancelarii królewskiej. W świetle praktyki kancelarii z drugiej połowy XVI w. właśnie do tzw. „sekretarzy piszących” (secretarii scribentes) należał obowiązek układania konceptów w uzgodnieniu z kanclerzami. Po zaakceptowaniu przez nich treści konceptów przekazywano je do przepisania niższemu personelowi a więc pisarzom (notarii, scribae) ${ }^{65}$. Teksty oblat uniwersałów jedynie ogólnikowo określały rodzaj uwierzytelniających je pieczęci ${ }^{66}$, dlatego ich analiza z konieczności musi być pominięta.

Uproszczonym zestawem formuł oraz obecnością niektórych z nich (salutacja) uniwersały przypominają mandaty piętnastowiecznej kancelarii królewskiej ${ }^{67}$. Lecz rozbudowana treść niektórych formuł (narracja, dyspozycja) upodobnia je do listów. I zjawisko to wydaje się całkiem naturalne, bowiem kierowane były one do przedstawicieli stanu stanowiącego podmiot życia politycznego, nie tylko po to by im nakazywać, lecz również przekonać do słuszności wydawanych zarządzeń.

$* * *$

W świetle przedstawionych ustaleń wyraźnie widać sprawczą rolę uniwersałów królewskich, szczególnie w procesie formowania oddziałów pospolitego ruszenia i kierowania ich do miejsc koncentracji. Bez tych dokumentów trudno sobie w ogóle wyobrazić legalną mobilizację szlachty, pocztów miejskich czy wybrańców. Ich rolę tutaj można porównać tylko z uniwersałami dotyczącymi ściśle spraw politycznych, na podstawie których zwoływano sejmiki szlacheckie. Wszelkie samowolne działanie ze strony osób, na których ciążył obowiązek służby wojskowej, miałoby charakter buntu czy w przypadku szlachty rokoszu, a więc związku nielegalnego i zwróconego przeciwko królowi. Dobrze ilustruje ten problem manifestacja dokonana w aktach grodu chełmskiego w r. 1670. Oto dwaj sołtysi z dóbr królewskich Hac Iwaszkiewicz z Czułczyc oraz Wasil Maksymowicz z Kosina, działając w imieniu własnym i innych sołtysów wsi z terenu starostwa chełmskiego (Strupina, Ochoży, Stulna i Ossowa) oświadczyli, że widząc wyprawę sołtysów z innych województw, a nie doczekawszy się odpowiednich uniwersałów hetmana oraz rotmistrza, dołączają swych pachołków do

\footnotetext{
${ }^{64}$ Ibid., sygn. 91, s. 272 (5 VII 1672 r.).

${ }^{65}$ A. Tomczak, Kilka uwag o kancelarii królewskiej..., s. 238-239.

${ }^{66} \mathrm{~Np}$. oblatując uniwersał z lipca $1653 \mathrm{r}$. podano, że uwierzytelniała go pieczęć wielka koronna. APL, Agch, RMO, sygn. 74, k. 400.

${ }^{67}$ I. Sułkowska-Kurasiowa, Dokumenty królewskie i ich funkcja..., s. 54.
} 
wcześniej sformowanych oddziałów ${ }^{68}$. Dokonany wpis manifestacji miał więc legalizować śmiałe, choć pozbawione podstaw prawnych, działanie chłopów, dobrze świadcząc o ich poczuciu odpowiedzialności.

Samo wydanie uniwersałów, stwarzających prawne podstawy akcji wojskowej szlachty, nie wystarczało jednak do sprawnego jej przeprowadzenia. Konieczne stawało się współdziałanie urzędów i kancelarii grodzkich. Zapewniały one publiczne ogłoszenie treści dokumentów oraz wpisanie do akt, by każdy nawet w po upływie czasu mógł zaznajomić się z ich treścią. Udział zapowiadanych $\mathrm{w}$ formule publikacyjnej magistratów i parafii miał tutaj, w porównaniu z grodami, znaczenie raczej drugorzędne ze względu na fakt, że jedynie uczestniczyły w przekazywaniu treści zarządzenia królewskiego najbliższemu otoczeniu i nie miały prawa ani obowiązku aktykacji tego typu uniwersałów.

Warto również zastanowić się nad faktycznym znaczeniem uniwersałów, a więc rolą jaką odgrywały w procesie formowania wojska szlacheckiego. I tutaj można podać dwa skrajne przykłady. Pozytywnego dostarczają wypadki z roku 1649 , kiedy to przeważające oddziały kozacko-tatarskie otoczyły nieliczne wojsko koronne dowodzone przez ks. Jeremiego Wiśniowieckiego pod Zbarażem. Wiśniowiecki bronił się kilka tygodni, ale wobec zdecydowanej przewagi wroga siły jego słabły i potrzebna mu była pomoc. Na podstawie wici wydanych $9 \mathrm{~V}$ (podwójne) oraz 20 VII (trzecie) zmobilizowano szlachtę z niektórych województw i ziem, wśród których znalazła się również ziemia chełmska. Zebrane wojsko pod dowództwem króla Jana Kazimierza wyruszyło na odsiecz, lecz przy przeprawie przez Strypę 15 VIII zostało zaatakowane i okrążone przez Kozaków i Tatarów. Atak odparto, ale cała armia królewska znalazła się w matni. Na szczęście w porę podjęto rokowania, które doprowadziły do chwilowego rozejmu (ugody zborowskiej).

W czasie chwilowego zawieszenia broni, poprzedzającego decydującą batalię wojny polsko-kozackiej, krytyce poddano zbyt późny termin wydania trzecich wici $^{69}$. Było to o tyle uzasadnione, że król wyruszył przeciwko Kozakom już pod koniec czerwca, a więc niemal na miesiąc przed wydaniem trzecich wici. Szlachta niektórych województw, m.in. lubelskiego, nie była przygotowana odpowiednio wcześniej, bowiem król na cztery dni przed ogłoszeniem trzecich wici, wyznaczających termin stawienia się u boku królewskiego na 28 VII,

${ }^{68}$ Manifestowali, że „.... wedtug prawa pospolitego i powinności swojej gotowi byli wcześniej pachotków ze wszytkiem porzqdkiem do obozu na ustugę Rzeczypospolitej wyprawić ale dotychczas uniwersatów ani Jaśnie Wielmożnego Jego Mości Pana Hetmana Wielkiego Koronnego ani od Jego Mości Pana Rotmistrza swego nie mieli, których dotychczas troskliwie wyglqdali na które by im miejsce isc kazano. Atoli widząc, ze z innych województw wyprawa sottyska teraz idzie zaraz té̇ swoich pochołków tejże godziny wespót z przechodzącymi wyprawujq̨ i na ustugę wysytajq....". Ibid., APL, Agch, RMO - luźne, sygn. 3, k. 166.

${ }^{69} \mathrm{~W}$ instrukcji wydanej 11 X 1649 r. posłom chełmskim miejscowa szlachta domagała się by wyjaśnili oni kto zawinił, że trzecie wici wydano nierychto i nieporzqdnie. Ibid., Akta grodzkie krasnostawskie (dalej: Agk), RMO, sygn. 1, k. 206v. Por. także J. Wimmer, Wojsko polskie..., 
wydał inny uniwersał nakazujący przegląd szlachty i jej tzw. popis, polegający na sporządzeniu ewidencji wszystkich obecnych, i przesuwający termin zgromadzenia na 11 VIII 1649 r. ${ }^{70}$ Skoro więc nawet opóźnione wydanie wici nie przekreśliło udziału w walce oddziałów niektórych ziem, to wcześniejsze wysłanie uniwersałów na pewno przyczyniłoby się do powiększenia armii królewskiej w decydującym momencie.

Negatywny przykład, o którym warto szerzej wspomnieć, dotyczy roku 1672. Wobec zagrożenia tureckiego król Michał Korybut Wiśniowiecki zdecydował się na wydanie 5 IV 1672 r. podwójnych wici, nakazujących rozpoczęcie przez szlachtę i miasta przygotowań do wojny ${ }^{71}$. Na sejmiku, który zebrał się 27 IV, wyznaczono popis pospolitego ruszenia $(1 \mathrm{~V})^{72}$. Trzecie wici wydane pod datą 5 VII wskazały miejsce zbiórki szlachty pod Hrubieszowem na dzień 16 $\mathrm{VIII}^{73}$. Przed planowanym wyruszeniem pospolitego ruszenia odbył się w Chełmie w dniu 20 VII sejmik ziemski, na którym szlachta podjęła jednak decyzję, że wyruszy dopiero po nadciągnięciu innych województw (tzw. górnych, czyli krakowskiego i sandomierskiego).

W tym czasie dotarł już do grodu uniwersał hetmana wielkiego koronnego Jana Sobieskiego, datowany na 10 VIII, w którym informował on o agresji tureckiej, zajęciu przez napastników Żwańca i spodziewanym szturmie Kamień$\mathrm{ca}^{74}$. Popis pospolitego ruszenia odbył się w wyznaczonym terminie, ale nie stanowił początku działań wojennych. Chełmianie, stwierdziwszy że ,inne województwa jeszcze nie kupią się”, rozjechali się do domów ${ }^{75}$. Powolność koncentracji chorągwi pospolitego ruszenia zmusiła monarchę do dramatycznego wezwania, by szlachta przybywała , do jego boku”, które znalazło swój wyraz w uniwersale z $23 \mathrm{VIII}^{76}$. Od wydania pierwszych wici minęły już 4 miesiące, a oczekiwane i potrzebne do walki siły szlacheckie jeszcze nie wyruszyły w pole. Na kolejnym sejmiku, tym razem deputackim, w dniu 12 IX „stosując się do trzech wici i uniwersału świeżo wydanego Jego Królewskiej Mości” ustalono kolejny termin zbrojnego stawiennictwa na 15 września pod Chełmem. Obrano też dowódcę (ductora) pospolitego ruszenia, którym z powodu nieobecności kasztelana Jana Piaseczyńskiego został podczaszy chełmski Samuel Regowski ${ }^{77}$.

Pominięcie Piaseczyńskiego nie zyskało aprobaty części szlachty. Gdy ten rozpoczął starania o odzyskanie komendy, grupa ta opowiedziała się za nim. Większość jednak poparła zaprawionego w bojach Regowskiego. Nastapiło

${ }^{70}$ APL, Akta grodzkie lubelskie, (dalej: Agl), RMO, sygn. 77, k. 600v-601.

${ }^{71}$ Ibid., RMO, sygn. 91, k. 139-141.

72 Ibid., k. 174v.

${ }^{73}$ Ibid., k. 270v-272; H. Gmiterek, Rejestry szlachty chetmskiej z lat 1669-1672, „Rocznik Chełmski", t. 2, 1996, s. 335.

${ }_{75}^{74}$ APL, Agch, RMO, sygn. 91, k. 312-313.

${ }^{75}$ Ibid., k. 313-316; H. Gmiterek, op. cit., s. 335-336.

${ }_{77}^{76}$ APL, Agch, RMO, sygn. 91, k. 320-320v.

${ }^{77}$ Ibid., k. 342-343. 
więc faktyczne rozbicie szlachty chełmskiej na dwie grupy, pozostające ze sobą w ostrym konflikcie. Wzięły one udział w pospolitym ruszeniu, ale oddzielnie. Jak wiadomo, bardzo wolno zbierająca się szlachta nie zdążyła sprawdzić się w walce z powodu upadku Kamieńca i podpisania poniżającego dla Rzeczpospolitej traktatu buczackiego 18 X $1672 \mathrm{r}$.

Rola uniwersałów zależała więc bezpośrednio od sytuacji politycznej i postawy szlachty. Jeśli szlachta nie wykazywała chęci do walki, to dokumenty królewskie odnosiły jedynie połowiczny skutek. Wojsko szlacheckie zbierało się wtedy, obradowało, podejmowało uchwały, ale nie walczyło.

Uniwersały powołujące szlachtę pod broń obok podstawowego znaczenia militarnego zawsze miały kontekst polityczny. Pospolite ruszenie bowiem okazać się mogło niebezpiecznym instrumentem, potencjalnie zdolnym do pokrzyżowania planów królewskich. Dobrze to rozumieli polscy królowie i ich otoczenie polityczne. Właśnie zwlekanie z wydaniem trzecich wici w 1649 r. zdaniem niektórych historyków spowodowane było obawami żywionymi przez ówczesnego kanclerza Jerzego Ossolińskiego przed szlachtą i jej żądaniami ${ }^{78}$.

Swojej siły w ramach pospolitego ruszenia świadoma była również szlachta. W schyłkowym okresie panowania Jana Kazimierza w roku 1667, znając zamiary abdykacji króla, jednocześnie obawiała się z jego strony bezprawnej elekcji następcy przed złożeniem korony (vivente rege), którym miał być mało popularny kandydat popierany przez Francję. Sytuacja militarna również nie układała się pomyślnie wobec ciągłych napadów tatarskich, dlatego domagano się wydania przez króla trzecich wici, licząc na to, że w obliczu siły zbrojnej król nie zdecyduje się na żaden ryzykowny i niemający poparcia szlachty krok ${ }^{79}$. Wici te istotnie wydano ale po kilkumiesięcznej zwłoce $\mathrm{i}$ to $\mathrm{w}$ terminie korzystnym dla dworu (17 X 1667 r.). Dzień wcześniej bowiem niebezpieczeństwo tatarskie zostało oddalone dzięki zwycięstwu hetmana polnego koronnego Jana Sobieskiego pod Podhajcami, ponadto zbliżała się pora zimowa, raczej nieodpowiednia do działań wojennych ${ }^{80}$.

Obok roli militarnej i politycznej uniwersały królewskie odnoszące się bezpośrednio do spraw wojskowych pełniły również, tak jak i inne uniwersały, funkcje informacyjno-propagandowe i to nie tylko wobec szlachty, ale wszystkich warstw i grup społecznych. Mieszczanie i chłopi z reguły nie brali bezpośredniego udziału w walkach, ale na pewno byli zainteresowani wieściami, które dotyczyły ich bezpieczeństwa, a teren ziemi chełmskiej, podobnie jak i terytoria innych ziem województwa ruskiego, podolskiego, wołyńskiego, lubelskiego czy podlaskiego narażony był na napady tatarskie czy kozackie. Można przypuszczać, że w związku z powszechnym zainteresowaniem i troską o własne bezpie-

${ }^{78}$ W. Konopczyński, Dzieje Polski nowożytnej, Warszawa 1986, s. 8.

${ }^{79}$ W. Czermak, Ostatnie lata życia Jana Kazimierza, wyd. A. Kersten, Warszawa 1970, s. 283-284; W. Kłaczewski, Abdykacja Jana Kazimierza. Spoteczeństwo szlacheckie wobec kryzysu politycznego lat 1667-1668, Lublin 1993, s. 58, 71,81.

${ }^{80}$ W. Kłaczewski, op. cit., s. 81; W. Czermak, op. cit., s. 284-285. 
czeństwo stereotypy ${ }^{81}$ upowszechniane tą właśnie drogą przenikały umysły odbiorców znacznie łatwiej niż jakiekolwiek inne treści. Czy tak rzeczywiście było - odpowiedzieć mogą jedynie dalsze badania.

Nie ulega wątpliwości propagandowa rola uniwersałów. Instrumentarium propagandowe wykorzystywane w nich nie było szczególnie wyszukane, składało się z kilku prostych środków. Przede wszystkim starano się odbiorcę przekonać o konieczności walki z wrogiem, odwołując się do jego różnorodnych interesów. W uniwersale królewskim z 26 IV 1614 r. wskazano aż pięć powodów, dla których szlachta chełmska powinna walczyć z Turkami. Na pierwszym miejscu postawiono miłość ojczyzny, następnie wspomniano o konieczności zachowania wolności szlacheckiej i gwarantujących ją praw. Dalsze miejsce zajął motyw zobowiązania wobec przodków, którzy byli twórcami wolności szlacheckich i przekazali je swoim następcom. Wzgląd na bezpieczeństwo samej szlachty oraz jej majątków a także konieczność zachowania ich dla przyszłych pokoleń ${ }^{82}$, znalazły się na samym końcu.

Inny używany środek przekonywania do idei walki z wrogiem stanowiło dążenie do wywołania lub wzmacniania niechęci do wroga przez upowszechnianie jego negatywnego stereotypu ${ }^{83}$. Przez cały czas utrzymywał się złożony z cech ujemnych obraz Turków i Tatarów, traktowanych zawsze łącznie jako niebezpieczna siła. W pierwszych dwóch dziesięcioleciach zestaw cech, które im przypisywano nie był tak skrajnie negatywny jak później. Car turecki określany był początkowo nie tyle jako jawny wróg lecz jako niepewny przyjaciel, przejawiający względem Rzeczypospolitej złe zamiary ${ }^{84}$. W miarę narastania konfliktu Turcy z Tatarami stawali się „pogaństwem”, któremu nienawiść religijna nakazywała stale czyhać na zgubę Rzeczypospolitej ${ }^{85}$, wiarołomnym oraz żądnym krwi chrześcijańskiej ${ }^{86}$, i tak już pozostało do końca wieku.

Innym wrogiem, któremu w propagandzie uniwersałów przypisywano jednoznacznie negatywną konotację byli Kozacy. Ale stało się to dopiero po wybuchu powstania Chmielnickiego, wcześniej bowiem w ogóle o nich nie wspominano. Gdy zaczęli zagrażać bezpieczeństwu państwa zaczęto kształtować ich

${ }^{81}$ Stereotypy w ujęciu twórcy ich teorii Waltera Lippmana są obrazami poszczególnych aspektów rzeczywistości, które nie zostały ukształtowane w bezpośrednim $\mathrm{z}$ nią kontakcie, ale są produktem społeczeństwa czy środowiska kulturalnego, przekazanym za pośrednictwem instytucji lub osób. Zob. J. Sztumski, Propaganda - jej problemy i metody, Katowice 1990, s. 46.

${ }^{82}$ APL, Agch, Inscriptiones, sygn. 17, k. 411 v-412. Podobnie w uniwersale z 8 VI 1618 r. Ibid., sygn. 18, k. 254-254v.

${ }^{83} \mathrm{O}$ językowych środkach deprecjonowania wroga używanych współcześnie piszą B. DobekOstrowska, J. Fras i B. Ociepka, Teoria i praktyka propagandy, Wrocław 1997, s. 101.

${ }^{84}$ APL, Agch, RMO, syg 17, k. 411 v-412 (26 IV 1614 r.); Ibid., k. 423-424 (23 V 1614 r.).

85 ,....Baczymy snadnie i każdy uważyć może jaka z tym pogaństwem powinność pokoju i jako się na ich ubezpieczenie spuszczać, którzy rzeczom swym folgując nalegają a pogodną niegotowość upatrzywszy okazyją z tych swoich i przeciwko chrześcijaństwu wszystkiemu zawziętych zamysłów wykonywać nie zaniechywają...”. Ibid., Inscriptiones, sygn. 18, k. 254-254v (8 VI 1618 r.).

${ }^{86}$ Ibid., k. 348-349 (20 IX 1618 r.) 
negatywny wizerunek. Określano ich jako „wyuzdane na zgubę państw naszych poddaństwo" "87 świętokradczych buntowników ufnych w swą siłę i dążących do unicestwienia Rzeczypospolitej i Polaków w ogóle ${ }^{88}$. Później zestaw ujemnych cech nowego wroga uzupełnią krzywoprzysięstwo, o które oskarżano Chmielnickiego (za niedotrzymywanie zawartych z Rzeczpospolitą traktatów) ${ }^{89}$, nienawiść do wiary katolickiej i szlachty ${ }^{90}$, wiarołomstwo okazane królowi polskiemu jako pomazańcowi bożemu ${ }^{91}$, sprzymierzanie się z poganami ${ }^{92}$.

Negatywny obraz nieprzyjaciela kształtowano również pośrednio. Miał go kompromitować w oczach odbiorców szlacheckich jego niecny sposób postępowania. W uniwersale z 14 V 1620 r. świadomie zredukowano opis wydarzeń do faktów uzasadniających pozytywny obraz działań króla, wroga zaś malujących w czarnych barwach. Była to tzw. dysymulacja, należąca do bardziej znanych technik propagandowych ${ }^{93}$. Król Zygmunt III Waza przedstawiony został jako zwolennik pokoju, pragnący ugody zarówno z sułtanem tureckim jak i chanem tatarskim. To dzięki jego wysiłkom doszło do zawarcia między stronami układu pokojowego. Jednak wiarołomni poganie zerwali go i rozpoczęli wojnę. Mimo to polski monarcha wstrzymywał się z ogłaszaniem wici i wysłał nawet posła Hieronima Otwinowskiego, by próbował zawrzeć pokój, godząc się na ustępstwa. Nie przyjęto go jednak, a łamiąc dobry obyczaj nawet nie wyznaczono mu kwatery, „sługi zelżono a przymierza nie chciano”. Jedynym więc rozwiązaniem zaistniałej sytuacji musiała być wojna ${ }^{94}$.

Obraz taki oczywiście nie bardzo przystawał do ówczesnej skomplikowanej sytuacji. H. Otwinowski przybył do Konstantynopola w marcu 1620 r. Rzeczywiście wbrew zwyczajowi odmówiono mu kwatery, zezwalając jedynie na wynajęcie jej pod Konstantynopolem na własny koszt. Nie mógł uzyskać audiencji u sułtana, a nawet zezwolenia na wjazd do stolicy, z Turkami zaś musiał się porozumiewać wyłącznie za pośrednictwem Mollarta, posła cesarza niemieckie$\mathrm{go}^{95}$. Ale takie postępowanie ze strony Turcji miało swoją przyczynę. Wiadomo bowiem, że wbrew zawartemu z nią w r. 1619 traktatowi Rzeczypospolita niewiele robiła, by ukrócić łupieżcze napady kozackie na położone na terytorium

${ }_{88}^{87}$ Ibid., Agkr, RMO, sygn. 1, k. 141 v-142 (uniwersał z 20 VII 1649 r.).

${ }_{88}, \ldots .$. widzimy największe i najpewniejsze niebezpieczeństwo Rzeczypospolitej od wyuzdanej buntowników swawoli imminere, która coraz większą górę bierze i ufność o sile swej i postronnych poprzysiężonych na ostatnią zgubę Rzeczypospolitej i wykorzenienie imienia polskiego...".

lbid., k. 685-686 (5 III 1651 r.).

${ }^{89}$ Ibid., k. 1240-1241 (9 VI 1652 r.).

${ }_{91}^{9}$ Ibid., Agch, RMO, sygn. 74, k. $143 \mathrm{v}-144$ (14 VI 1652 r.).

${ }_{92}$ Ibid., k. 398v-400 (VII 1653 r.).

${ }_{93}$ Ibid. ${ }^{93}$ M. Szulczewski, Propaganda polityczna. Zarys problematyki teoretycznej, Warszawa
1975 , s. 127; U. Augustyniak, Informacja i propaganda w Polsce za Zygmunta III, Warszawa
1981, s. 118 . 1981 , s. 118
${ }_{95}^{94} \mathrm{NGAB}$, f. 1740 , op. 1 , ed. 4 , k. $178-179 \mathrm{v}$.
${ }^{95}$ L. Podhorodecki, Stanistaw Koniecpolski ok. 1592-1646, Warszawa 1978, s. 60. 
tureckim wybrzeża Morza Czarnego. Już w momencie podpisywania układu pokojowego Kozacy pod dowództwem Borodawki złupili Warnę. Od momentu przybycia posła aż do wydania uniwersału $(14 \mathrm{~V})$ Kozacy co najmniej trzy razy atakowali posiadłości tureckie ${ }^{96}$. W kwietniu wyprawa kozacka zapuściła się aż pod Konstantynopol. W relacji jednego z polskich wysłanników, zapewne przesadnej, ale oddającej atmosferę zagrożenia stolicy imperium, sułtan „Osman widząc ognie od pożarów z okien pałacu omal ze strachu nie umarł"" "Zresztą ataki nie ustały także później.

Nie można się więc dziwić, że wysłannika króla polskiego, którego obwiniano o tolerowanie wypadów kozackich przyjęto wrogo. W tej sytuacji mowy być nie mogło nie tylko o ,przymierzu”, o którym wspominał uniwersał, ale nawet o jakichkolwiek pertraktacjach. Dopiero później polskiego posła dopuszczono do wielkiego wezyra Ali paszy, ale audiencja nie przyniosła żadnych skutków. Otwinowski widząc brak szans na powodzenie swojej misji potajemnie wymknął się z Turcji i przez Wenecję powrócił do kraju ${ }^{98}$.

W innych uniwersałach używano innego sposobu, mianowicie propagowania wyłączenie pozytywnego wizerunku własnej osoby, czyli króla. Akcentowano przy tym jego troskę o dobro Rzeczypospolitej ${ }^{99}$ i poświęcenie ${ }^{100}$. Ten schemat uzupełniano eksponowaniem jego łagodności, wyrozumiałości oraz dążenia do zachowania pokoju, kontrastujących $\mathrm{z}$ odmiennym postępowaniem powstańców kozackich ${ }^{101}$. Również starano się podkreślać jego zgodne współdziałanie ze szlachta, sejmem oraz senatorami-rezydentami, stale przebywającymi na jego dworze $^{102}$. Stanowić ono miało dodatkową gwarancję słuszności podejmowanych przez monarchę decyzji.

${ }^{96}$ R. Majewski, Cecora rok 1620, Warszawa 1970, s. 45.

${ }^{97}$ Ibid.

${ }^{98}$ B. Baranowski, Znajomość Wschodu w dawnej Polsce do XVIII w., Łódź 1950, s. 83.

99 „... Jako po te czasy nic nie schodziło Rzeczypospolitej na czułości naszej i ojcowskim domyślawaniu w tym co dla zatrzymania całości i bespieczeństwa jej zależało...”. APL, Agk, RMO, sygn. 1, k. 650v (5 I 1651 r.).

${ }^{100}$, ,... inaczej nie baczemy rezydencyjej tylko o zgromadzone wszystkie Rzeczypospolitej siły do czego my osobą naszą przykładać się chcemy, niosąc zdrowie i dostojeństwo nasze za całość i bezpieczeństwo państw nam od Pana Boga powierzonych...”. Ibid., k. 685-686 (5 III 1651 r.).

${ }^{101}, \ldots .$. Nieśliśmy i my głowy nasze za powierzony lud, aby go w dalszy wprowadzić pokój a tenże Pan zastępów nie odjął śmiałości chłopstwa, aby na pomazańca swego wojować nie miało pokazywaliśmy im królewską łaskę, w zapomnienie puszczając przeszłe ich zbrodnie tym skutkiem, aby się więcej krew chrześcijańska nie lała...". Ibid., Agch, RMO, sygn. 74, k. 398v-400 (VII 1653 r.).

102, ,... stosując się do ochoty tychże województw i prośby przez posłów nam przełożonej de consilia senatus postcomitiali dajemy te trzecie wici...”. Ibid., Agch, RMO, sygn. 91, k. 270v-271 (5 VII 1672 r.). 
Często wskazywano na ingerencję boską ${ }^{103}$, a klęski spadające na kraj w czasie powstania Chmielnickiego uznawano za karę Bożą, którą spowodowały popełnione grzechy. Król brał część odpowiedzialności na siebie ${ }^{104}$, w czym należy dopatrywać się nie tyle skłonności do autokrytycyzmu, ale raczej chęci skłonienia szlachty do analizy własnego postępowania. Ale prowidencjalna interpretacja przyczyn nieszczęść trapiących ówczesną Rzeczypospolitą mogła mieć także racjonalne korzenie. Doszukiwanie się jej w boskim wyroku dawało nadzieję wyjścia z opresji. Skoro Bóg ukarał naród szlachecki zsyłając na niego nieszczęścia, to mógł odwrócić swój gniew i wydobyć go z utrapień. Dwadzieścia lat później, gdy Rzeczpospolita mimo tylu niepowodzeń przetrwała okres najazdów dostrzeżenie ingerencji Opatrzności przychodziło znacznie łatwiej ${ }^{105}$.

Można zauważyć również inny chwyt propagandowy - unikanie otwartej krytyki sojusznika, jakim była szlachta. Traktowano ją z rewerencją, podkreślając pozytywne jej cechy, takie jak miłość ojczyzny oraz gotowość do obrony kraju $^{106}$, jak również odwagę ${ }^{107}$. Unikano negatywnych ocen postępowania szlachty. Nawet jeśli dochodziło do zerwania sejmu i pokrzyżowania królewskich planów, to o wypadkach tych informowano bardzo oględnie, bez formułowania jakichkolwiek ocen krytycznych pod adresem kłopotliwego sojuszni$\mathrm{ka}^{108}$. Zamiast ostrych wyrzutów pozwalano sobie na ironię ${ }^{109}$, a nawet szyderstwo $^{110}$. Ale sytuacja w roku 1672 była zupełnie wyjątkowa, bowiem krajowi

${ }^{103}$,... Przyznać to Majestatowi Boskiemu musiemy, że nas tak chce przed sobą upokorzyć, abyśmy wszyscy w uniżonych przyznali sercach, iż bez jego wszechmocnej ręki i leda motłochu wiarołomnych poddanych naszych tak długo przewojować nie możemy...”. Ibid., sygn. 74, s. 398v (VII 1653 r.).

104 ,.... Bóg Pan wszystkich zastępów za grzechy nasze dotąd nieubłaganą z niedoścignionych i niepojętych wyroków swoich pokarał w tych dniach utrapioną ojczyznę naszą...". Ibid., syg 74, k. $138-138 v$ (9 VI 1652).

105 ,... Lubo na oko widome woli i łaski Bożej dowody kiedy post liminio powróciły ukrainne prowincje i miasta potężne do naszego i Rzeczypospolitej poddaństwa tak dalece, iż czego bellicus labor przez lat przeszło dwadzieścia odebrać nie mógł, jedna kampania za błogosławieństwem boskim a odwagą wielmożnych wodzów, dzielnością wojska ad subiectionem przywiodła...". Ibid., Agch, RMO, sygn. 91, k. 270v-271(5 VII 1672 r.).

106 ,... przychodzi nam na ten czas uciekać się do samej chęci i gotowości tych, którzy ojczy-

zny i całości jej prawdziwie miłuja...”. Ibid., Inscriptiones, sygn. 14, k. 604-605 (8 VI 1605 r.).

${ }^{107}, \ldots . .$. nic nie wątpimy, że Uprzejmości i wierności Wasze równem affectem, chęcią i odwa-

gą do obrony tejże ojczyzny pospieszyć się i do boku naszego przybyć zechcą...". Ibid., Agkr,

RMO, sygn. 1, k. 650v-651v (5 I 1651 r.).

${ }^{108} \mathrm{Z}$ wielką ostrożnością wypowiadano się o zerwaniu sejmu w r. 1672. „... Ta która wszyst-

kim Boskim dziełom zwyczajnie sprzeciwiać się zwykła indignitas nie przestaje mieszać harmoniam rad publicznych, gdy a to znowu sejm tak bardzo potrzebny aeterno imperii vulnere rozerwała, wydając prawie na zgubę następującej nawale pogańskiej...”. Ibid., Agch, RMO, sygn. 91, k.

270v (5 VII 1672 r.).

potym w "... Ujmijcie sobie Uprzejmości i Wierności Wasze nam mili choć trochę wczasu, abyście 110 wiecznym opływali pokoju...”. Ibid., sygn. 74, k. 398v-399 (VII 1653 r.).

kiedyszkolwiek Alećby i by znośniejszą rzecz by była gdybyśmy przynajmniej i o tej już obronie serio dopiero po szkodzili i na sobie staropolskiego przysłowia miserum in modum nie odnawiali, że 
groziła nawała turecka, wobec której pozostawał niemal bezbronny. Użyta wtedy argumentacja miała raczej wstrząsnąć adresatem niż go przekonywać. Konkluzja, że „opuszczać ręki nie godzi się i dobrowolnie szabli pogańskiej szyję odkrywać" odzwierciedlała desperację obozu królewskiego, podobnie jak przywołany argument, że skoro zwierzęta zostały obdarzone przez naturę zdolnością do obrony w chwili zagrożenia ${ }^{111}$, to tym bardziej posiadają ją ludzie. Ten przypadek zerwania z zasadą niedrażnienia szlachty można jednak uznać za odosobniony.

Rolę swoistego środka dopingującego szlachtę spełniał inny chwyt o znaczeniu propagandowym, jakim było wyolbrzymianie zagrożenia, tak, by szlachta nabrała niezachwianego przekonania, że od jej udziału w wyprawie zależy dalsze istnienie Rzeczypospolitej, a wszelkie niepowodzenie będzie równoznaczne $\mathrm{z}$ końcem istnienia państwa. ${ }^{112}$

Jego odwrotność stanowiło z kolei przecenianie własnej słabości, które miało odgrywać podobną rolę, co zabieg omówiony wyżej ${ }^{113}$.

Przedstawiony przegląd problemów wynikających z wstępnego badania siedemnastowiecznych uniwersałów królewskich, skłaniać musi do wniosku, że stanowiły one ważny produkt kancelarii królewskiej, który nie powinien wymykać się z pola widzenia nowożytnej dyplomatyki, lecz stanowić przedmiot dalszych dociekań. Szczególnie ważna wydaje się weryfikacja w toku dalszych badań wniosków płynących z przeprowadzonej analizy. Oto one:

dusz chrześcijańskich w pogańską niewolę - niepowetowane sami sobie zarządzimy...". Ibid., k.139-140v (5 IV 1672 r.).

111 Ibid.

112 ,... Mamy pewną wiadomość od wielmożnego Stanisława Koniecpolskiego wojewody sandomierskiego, hetmana naszego o następujących od pogan Turków jako i Tatarów niebezpieczeństwach, którzy się z wielką mocą do państw naszych gotują i wkrótce potężną incursiq uczynić chcą i one szablą i ogniem plondrować i znosić posmakowawszy sobie tak częste i gęste plony i korzyści zamyśliwają.” Ibid., Inscriptiones, sygn. 20, k. 216-217 (19 VI 1626 r.). „... Tedy w tak ciężkim Rzeczypospolitej razie obawiając się, aby ten nieprzyjaciel dalej tu in viscera Regni nie postępował i zwyczajną prętkością reliqium tej Rzeczypospolitej, które dotąd a servitia et tyrranide hostilis wolne zostawały mieczem i ogniem znosić nie zechciał, ponieważ omni destitute auxilio zostawa Rzeczypospolita i tylko wspólnej sile Uprzejmości i Wierności Waszych szczególną ma nadzieję. Żądamy i napominamy, abyście ostatniej Rzeczypospolitej zapobiegając zgubie we wszelakiej byli gotowości i tam się do nas kupili...". Ibid., Agkr, RMO, sygn. 1, k. 1240-1241 (9 VI 1652 r). Ibid., Agch, RMO, sygn. 74, k. 143v-144 (14 VI 1652 r.).

${ }^{113}$ Patrz poprzedni przypis. ,... jeśli nas manus Rzeczypospolitej nie wesprze albo odmiana zamieszanie uchwały sejmowej zawiedzie, Bogu et posteritati odpowiadać będzie o niesforność i fatalis jakaś credulitas, która lethargo Rzeczypospolitej uśpiła, że zguby swej widzieć i czuć nie chce...". Ibid., Agch, RMO, sygn. 95, k. 188 (16 VI 1676 r.). 
1. Uniwersały stanowiły często spotykany produkt kancelarii królewskiej. Jego nazwa pochodzi od przymiotnika universalis (powszechny, ogólny), bowiem adresowano go do szerszego grona odbiorców.

2. Występowały jako odezwy, zarządzenia, polecenia, kierowane zarówno do odbiorców zbiorowych: stanów (szlachta ziemi lub powiatu), warstw społecznych (nobilitowani i indygenowani), osób określonej kategorii prawnej (wybrańcy), jak i pojedynczych osób (oficerowie). W tym ostatnim przypadku ich treść nie była adresowana wyłącznie do odbiorców, ale również innych osób czy urzędów.

3. Posiadały formularz skrócony składający się z intytulacji (zawsze pełnej) $\mathrm{z}$ formułą dewocyjną, promulgacji, inskrypcji (niekiedy łączonych), narracji, dyspozycji, formuły aktykacyjno-publikacyjnej. Dosyć rzadko zestaw formuł kontekstu uzupełniała koroboracja. Rolę środków uwierzytelniających pełniły podpis królewski oraz pieczęć. Podpis sekretarza królewskiego lub regenta kancelarii miał prawdopodobnie znaczenie kancelaryjne, wskazując urzędnika odpowiedzialnego za dyktat dokumentu.

4. Za pomocą uniwersałów królewskich zwoływano pospolite ruszenie szlachty w poszczególnych powiatach oraz ziemiach oraz kierowano nim aż do momentu połączenia $\mathrm{z}$ wojskami królewskimi lub hetmańskimi. Uniwersały służyły również do mobilizacji innych kategorii osób, na których ciążył obowiązek służby wojskowej (wybrańców, w określonych wypadkach nobilitowanych $\mathrm{i}$ indygenowanych).

5. Rola uniwersałów mobilizacyjnych nie ograniczała się wyłącznie do spraw militarnych. Stanowiły one w ręku królów również instrument polityczny, którego czasem używali jako środka realizacji celów w polityce wewnętrznej. Pospolite ruszenie było bowiem potężnym środkiem oddziaływania szlachty i musiały się z nim liczyć wszystkie siły ówczesnej Rzeczypospolitej, przede wszystkim król i magnaci.

6. W sytuacji zagrożenia państwa, gdy powołanie szlachty pod broń okazywało się nieodzowne, uniwersały stawały się również środkiem oddziaływania, wykorzystującym proste środki propagandowe. Były nimi: upowszechnianie wyłącznie negatywnego obrazu przeciwnika oraz zredukowanego wizerunku działań własnych wyłącznie do pozytywów, podkreślanie zalet najbliższego sojusznika (szlachty), unikanie jego bezpośredniej krytyki, natomiast czynienie tego w sposób pośredni, przez pomniejszanie wagi jego sukcesów (np. przez wskazywanie, że bardziej stanowią one zasługę Opatrzności). Przeceniano zagrożenia ze strony przeciwnika, wyolbrzymiano jednocześnie słabość Rzeczypospolitej.

7. Dzięki oblatom grodzkim i ogłaszaniu ich treści szerokim rzeszom ówczesnego społeczeństwa w miastach oraz w parafiach dostarczano ważnych dla nich informacji o sytuacji polityczno-militarnej państwa. 8. Siedemnastowieczne dokumenty, jakim były uniwersały, nawiązując bu-
dową do średniowiecznych mandatów wyróżniały się bogactwem treści. Oprócz 
informacji militarnych przynosiły szereg danych o sytuacji politycznej oraz zestaw prostych środków propagandowych ukrytych pod kunsztowną formą retoryczną. Zyskiwały też niemal masowego adresata. Te ich znamiona, rzadkie jeszcze w okresie nowożytnym, upowszechniły się w czasach nam współczesnych w politycznych manifestach i odezwach pozbawionych znaczenia prawnego, także adresowanych do jak najszerszego kręgu odbiorców. 